\title{
Editorial: Adopting a multilingual stance: Benefits and challenges for learners and teachers
}

Shem Macdonald Editor

This issue of TESOL in Context picks up on themes running through a number of the presentations as well as the keynotes from the Australian Council of TESOL Associations (ACTA) Conference that took place in Adelaide on 3-5 October, 2018.

One of these themes was the readiness of teachers, both preand in-service, to adopt a positive view of learners of English as an Additional Language (EAL) and make productive use of the understandings, knowledges and skills that they bring to the classroom, specifically those related to the learners' language(s). All EAL learners, even those entering formal education at a very young age, come with proficiencies in (a) language(s) and/or dialect(s) other than Standard Australian English. In contrast to the expectation, as observed by Cummins et al. (2005), that learners leave their language(s) at the school door along with their social and cultural expertise, much current discussion and research around schools and other learning centres is actively considering ways to leverage these learner attributes for successful learning (e.g. Duarte, 2019).

Many associated issues were discussed during the 2018 Conference leading delegates and presenters to share their ideas, experiences and expertise based on their work and research in classrooms and on developing meaningful curricula and effective pedagogies. The notion of translanguaging, in particular, was foregrounded along with the different ways it is understood and plays out in diverse TESOL contexts. A burgeoning literature supports these discussions (e.g. Choi \& Ollerhead, 2018; French, 2018; García \& Wei, 2014; García \& Kleyn, 2016). Additionally, questions arose about how teachers (both TESOL and mainstream) use learners' other languages to support their learning of English; particularly, when teachers may have little or no knowledge of the languages spoken by them. Similar issues are discussed by Dooley and Vallejo (2020), who expose insecurities around the use of 
multilingual strategies in classrooms by in-service teachers. They ask, "Do I prepare materials to focus on language(s)? One language at a time? How do I support the use of the students' different resources? How do I assess their plurilingual and multimodal output?" (p. 93). These authors explore reasons for acceptance as well as tensions and challenges around implementing multilingual pedagogies. (See also Llompart et al. (2020) for a discussion on how plurilingual practices are resources for students' participation in classroom activities and need to be transformed into classroom teaching methodology). Even when there are known multilingual strategies there are challenges relating to educating teachers, both pre-service and in-service, TESOL and mainstream, and providing access to, and time for professional learning (as discussed by Barnes, Shwayli and Matthews in this issue).

These discussions and debates are taking place within Australia and internationally with teachers, researchers and others working in TESOL and languages education contexts. Educators puzzle over how to better understand and respond, and they question the kinds of educational perspectives and practices that prevail in many schools and whether these address the learning needs of all students. This has led to publications that include Turner's (2019) book focusing on multilingualism as a resource and a goal which argues for the learning and use of language, both foreign and heritage languages, across the curriculum in schools.

The authors of the three articles in this issue were all presenters at the 2018 ACTA national conference. Their work contributes positively to broader discussions around these topics and suggests alternative ways of understanding and responding to the needs of EAL learners.

Ester de Jong, an ACTA Conference keynote speaker, argues for "the reconceptualization of teacher education to explicitly and purposefully include linguistically and culturally responsive pedagogy in ... curriculum". Drawing on perspectives gained from teaching and researching in North America and other locations, de Jong is able to translate experiences and understandings that are relevant to, and challenge the Australian TESOL field. She argues for development of teachers, both pre- and in-service, fostering in them multilingual perspectives and promoting a multilingual stance essential for success in the education of linguistically and culturally diverse students. She emphasizes the importance of avoiding a monolingual bias within schools and classrooms and for the recognition that effective teaching of EAL 
learners is more than "just good teaching”. Developing pre-service teachers' multilingual pedagogies and stance, she argues, is necessary for the building of students' linguistic repertoires. She concludes by stating that this requires more than simply accepting the use of home languages in classrooms.

The need to incorporate students' home languages and cultural knowledge into teaching and learning, is similarly highlighted by Mei French in her article in which she argues for principles to guide the development of "effective multilingual and translanguaging approaches for linguistically diverse students." She outlines principles for multilingual curriculum and pedagogy reporting on work that explores how EAL learners and teachers engage or attempt to engage with such principles. Her research in an Australian secondary school follows the experiences of learners and teachers and reports on their multilingual pedagogical approaches in practice. One of the key outcomes of this work is gaining a better understanding of the importance of learner agency when engaging with multilingual approaches and how students adopt or do not adopt strategies suggested to them by their teachers.

Exploring teacher readiness to address the needs of EAL learners, Melissa Barnes, Seham Shwayli and Pamalee Matthews focus on the views of mainstream teachers and principals in two schools in regional areas of Victoria. They find that while there are some misconceptions about EAL learners around how long they need to reach age equivalent proficiency in English, generally teachers are positive about the learners' inclusion in classrooms. However, what clearly emerges from this research is the need for support through teacher professional development to assist teachers to work more effectively with such learners. One of the salient challenges they identify through their speaking with these teachers and principals relates to the issues of time for, and timing of this professional development.

Each of these papers makes a valuable contribution to our understandings of multilingual pedagogies and how the learning needs of plurilingual students in school [and adult] contexts might be better met through the adoption and development of a multilingual stance. Each article offers insights that have implications for practice by teachers in schools both those with a long history of teaching EAL learners (such as those in metropolitan areas) as well as schools where EAL learners have been welcomed more recently (such as is in many regional areas of Australia). 


\section{References}

Choi, J., \& Ollerhead, S. (Eds.). (2018). Plurilingualism in teaching and learning: complexities across contexts. New York: Routledge.

Cummins, J., Bismilla, V., Chow, P., Giampapa, F., Cohen, S., Leoni, L., et al. (2005). Affirming identity in multicultural classrooms. Educational Leadership, 63(1), 38-43. Available from http://www.ascd.org/publications/educationalleadership.aspx

Dooly, M., \& Vallejo, C. (2020). Bringing plurilingualism into teaching practice: a quixotic quest? International Journal of Bilingual Education and Bilingualism, 23(1), 81-97. doi:10.10 80/13670050.2019.1598933

Duarte, J. (2019). Translanguaging in mainstream education: a sociocultural approach. International Journal of Bilingual Education and Bilingualism, 22(2), 150-164. doi:10.1080/136 70050.2016.1231774

French, M. (2018). 'Translanguaging in the classroom'. Melbourne: Department of Education and Training FUSE. Available at: https://fuse.education.vic.gov.au/

García, O., \& Kleyn, T. (2016) (Eds), Translanguaging with multilingual students. Learning from classroom moments. New York, NY: Routledge.

García, O., \& Wei, L. (2014). Translanguaging: Language, Bilingualism and Education. Basingstoke, UK: Palgrave Macmillan.

Llompart, J., Masats, D., Moore, E., \& Nussbaum, L. (2020). 'Mézclalo un poquito': plurilingual practices in multilingual educational milieus. International Journal of Bilingual Education and Bilingualism, 23(1), 98-112. doi:10.1080/1367 0050.2019 .1598934

Turner, M. (2019). Multilingualism as a resource and a goal: using and learning languages in mainstream schools. Cham, Switzerland: Palgrave Macmillan. 